\title{
PREPARATION AND CHARACTERIZATION OF CHICKEN SKIN GELATIN AS AN ALTERNATIVE TO MAMMALIAN GELATIN
}

\author{
Norizah Mhd Sarbon ${ }^{1,2}$, Farah Badii ${ }^{1}$ and Nazlin K Howell ${ }^{1} *$
}

1. Faculty of Health and Medical Sciences, University of Surrey, Guildford, Surrey, GU2 7XH, UK.

2. Present address: Department of Food Science, Faculty of Agrotechnology and Food Science, Universiti Malaysia Terengganu, 21030, Kuala Terengganu, Terengganu, Malaysia.

*Corresponding author. Tel.: 00441483686448

Fax: 00441483686401

E-mail address: $\underline{\text { N.Howell@ } \text { surrey.ac.uk }}$ 


\begin{abstract}
The aims of this study were to report for the first time, the extraction and physicochemical properties of chicken skin gelatin compared to bovine gelatin. Extracted chicken skin gelatin $6.67 \%(\mathrm{w} / \mathrm{v})$ had a higher bloom value $(355 \pm 1.48 \mathrm{~g})$ than bovine gelatin $(259 \pm 0.71 \mathrm{~g})$. The dynamic viscoelastic profile of chicken gelatin exhibited higher viscous and elastic modulus values compared to bovine gelatin for a range of concentrations and frequencies. Thermal properties studied by differential scanning calorimetry (DSC) showed that the melting temperature of $6.67 \%$, chicken skin gelatin was significantly greater $(p<0.05)$ than that of bovine gelatin, indicating lower stability of bovine gelatin compared to chicken skin gelatin. Results obtained in this study showed that Gly (33.70\%), Pro (13.42\%), H.Pro (12.13\%) and Ala $(10.08 \%)$ were the most dominant amino acids in chicken skin gelatin which contributed to the higher gel strength and stability. Raman spectra of chicken skin and bovine gelatin were similar and displayed typical protein spectra. Chicken gelatin showed strong hydrogen bonding compared to bovine gelatin as the tyrosine doublet ratio $\left(I_{855 /} I_{830}\right)$ of chicken gelatin was significantly lower than that of bovine gelatin. Significantly, the alpha helix and $\beta$-sheet type structures were higher for chicken skin gelatin compared with bovine gelatin. The average molecular weight of chicken gelatin was 285,000 Da. These findings, obtained for the first time for chicken skin gelatin, show that it has high potential for application as an alternative to commercial gelatin.
\end{abstract}

Keywords: Chicken skin gelatin, gel strength, viscoelasticity, differential scanning calorimetry, Raman spectroscopy 


\section{INTRODUCTION}

Gelatin is a polypeptide produced by partial hydrolysis of collagen derived from animal skin, connective tissue and bones (Morrison et al., 1999). Gelatin is a special hydrocolloid, serving multiple functions with a wide range of applications in the food, pharmaceutical, photographic and cosmetic industries. The uniqueness of the gelatin is its ability to form thermoreversible gels with a melting temperature close to body temperature and its solublity in water (Zhou et al., 2006). In addition to gelation properties, gelatin also has applications as a colloid stabilizer, foaming agent and emulsifier (McClements, 2005). The estimated world usage of gelatin is reported at about 200,000 metric tonnes per year (Choi \& Regeinstein, 2000). Most available gelatins are manufactured from mammalian resources such as pig skin, cattle bones and cattle hide. However, other sources of gelatin are becoming increasing relevant, such as fish bone, scales and skin.

Gel strength or bloom value including low $(<150)$, medium (150-220) and high bloom (220-300) determines the quality of gelatin and viscoelastic properties such as gelling and melting. Rheological data are required for the analysis of flow conditions in different food processing operations and the measurement of texture (Binsi et al., 2009). Johnston-Bank, (1990) stated that the quality of gelatin depends on its physico-chemical properties, which are greatly influenced, not only by the species or tissue from which it is extracted, but also by the severity of the manufacturing method. The rheological properties of thermo-reversible gelatin gels are primarily a function of temperature and the concentration of gelatin for a given gelatin type.

The development of gelatin alternatives has gained importance in recent years as the demand for non-bovine and non-porcine gelatin has increased due to the BSE (bovine spongiform encephalopathy) crisis and for religious and social reasons. Since then, there has been much concern about using gelatin derived from possibly infected animal parts. Pig skin gelatin is not acceptable for Judaism and Islam and beef gelatin is acceptable only if it has been prepared according to religious requirements (Badii \& Howell, 2006). Therefore, the development of gelatin alternatives is highly desirable to food processors as the global market for food certified halal is growing rapidly (Karim \& Bhat, 2009). 
To date however, few alternatives for mammalian gelatin are available. A number of studies on developing gelatin alternatives to mammalian gelatin have been reported including from cod skin (Gudmundsson \& Hafsteinsson, 1997), horse mackerel skin (Badii \& Howell, 2006), sin croaker and shortfin scad skin (Cheow et al., 2007), black and red tilapia skin (Jamilah \& Harvinder, 2002), hake skin (Gomez-Guillen et al., 2002), yellowfin tuna (Chiou et al., 2006), harp seal (Arnesen \& Gildberg, 2007), and cat fish (Yang et al., 2007). Similarly, in South Korea investigations on the feasibility of using chicken feet to replace cowhides for jokpyun (traditional Korean gel-type food) have been undertaken (Jun et al., 2000). Additionally, there is growing interest in developing alternative substitutes of raw materials such as chicken bone and fishery by-products (Lim et al., 2001). To our knowledge, there are no reported studies on the production of gelatin from chicken skin and detailed physicochemical and rheological studies. As skin is a wasted by-product of poultry processing, it may be possible to replace mammalian sources of gelatin with gelatin extracted from chicken skin.

Therefore, the objectives of the present study were to prepare gelatin from chicken skin and to compare the physicochemical, thermal and rheological properties, of the extracted gelatin with commercially available bovine gelatin. The hypothesis is that avian gelatin may have comparable properties to mammalian gelatin based on the imino acids, secondary structure and molecular weight, that are important indicators for high bloom strength. Moreover, this novel research would also lead to maximizing the usage of under-utilised resources and industrial waste.

\section{MATERIAL AND METHODS}

\subsection{Materials}

Fresh chicken skins were obtained from a local market, Guildford, Surrey, UK and chilled in ice while transporting them to the laboratory, Faculty of Health and Medical Sciences, University of Surrey, Guildford, Surrey, UK. Upon arrival at the laboratory, the visible fat was mechanically removed, the skin was washed and weighed (wet weight) before storage at $-80{ }^{\circ} \mathrm{C}$ until used for further experiments. Chemicals for amino acids analysis including acetonitrile 
HPLC grade (BDH), sodium acetate, mixed resin (amberlite MB-6113), sodium hydroxide, sulphuric acid and Bloom jars (SCHOTTGLAS Mainz. Bloom test vessel, product no. 2112501) were obtained from Fisher Scientific, Loughborough, UK. Triethylamine (TEA), phenylisothiocyanate (PITC), amino acid standards for food analysis, silicone oil, citric acid, and commercial bovine gelatin (Type B) from bovine skin were obtained from Sigma-Aldrich Company Ltd, Poole, Dorset, UK. All reagents used were analytical grade.

\subsection{Methods}

\subsubsection{Chicken skin preparation}

Frozen chicken skins were thawed in a cold room $\left(4-5{ }^{\circ} \mathrm{C}\right)$ overnight. After thoroughly rinsing in excessive water to remove impurities, the skins were cut into $2-3 \mathrm{~cm}$ pieces and freezedried for about 4-5 days. Completely dry skins were ground before being defatted using the Soxhlet method (AOAC, 2006).

\subsubsection{Gelatin extraction}

Gelatin was extracted from chicken skin according to the method of Badii and Howell (2006) with slight modification. To extract gelatin, $14 \mathrm{~g}$ defatted dried chicken skin was mixed with $200 \mathrm{ml}$ sodium hydroxide $(0.15 \% \mathrm{w} / \mathrm{v})$. The mixture was shaken well and slowly stirred at room temperature $\left(22{ }^{\circ} \mathrm{C}\right)$ for $40 \mathrm{~min}$ before centrifuging at $3500 \mathrm{x} \mathrm{g}$ for $10 \mathrm{~min}$. This step was repeated three times. The alkaline solution was changed every $40 \mathrm{~min}$ to remove non-collagenous proteins and pigments. The alkaline treated pellets were rinsed with distilled water. The resulting pellets were then mixed with $200 \mathrm{ml}$ sulphuric acid $0.15 \%(\mathrm{v} / \mathrm{v})$. Again, the resulting pellets were mixed with $200 \mathrm{ml}$ of citric acid solution $0.7 \%(\mathrm{w} / \mathrm{v})$. The mixture was shaken well and stirred gently at room temperature for $40 \mathrm{~min}$ before centrifuging at $3500 \mathrm{x} g$ for $10 \mathrm{~min}$. The acid solution was changed every 40 min to denature the collagen in the chicken skin matrix. Each treatment was repeated three times and each treatment took about $2 \mathrm{~h}$ to complete. The pellets were then subjected to a final wash with distilled water to remove any residual salts followed by centrifuging at $3500 \times \mathrm{g}$ for $15 \mathrm{~min}$. The final extraction was carried out in distilled water at 
controlled temperature $\left(45^{\circ} \mathrm{C}\right)$ for overnight without stirring. The resultant mixture was filtered in a Büchner funnel with a Whatman filter paper (no.4) and deionised, using an Amberlite mixed bed resin (M B-6113) according to the GME Monograph Version 2000 (GME, 2000). The solution ionic strength was checked with a conductivity meter to obtain $50 \mu \mathrm{Siemens} / \mathrm{cm}$. The $\mathrm{pH}$ was adjusted to 6.0 with $0.1 \mathrm{M}$ sulphuric acid. The volume was reduced to $1 / 10$ by evaporation under vacuum (using a rotary evaporator) at $45{ }^{\circ} \mathrm{C}$ and then kept in the freezer overnight before freeze-drying. The dry matter was referred to as 'gelatin powder'.

\subsubsection{Characterisation of gelatin}

\subsubsection{Proximate analysis}

The moisture, ash and fat content of extracted gelatin were determined according to the methods described by AOAC (2006). The crude protein content was determined by estimating its total nitrogen content by the Kjeldahl method (AOAC, 2006). A factor of 5.55 was used to convert the nitrogen value to gelatin protein. The yield of gelatin was calculated based on dry weight of fresh skin using the following formula:

\section{Yield of gelatin $(\%)=\underline{\text { Weight of freeze-dried gelatin }} \times 100$ \\ Weight of dried skin}

\subsubsection{Determination of bloom strength of gelatin gels}

Bloom value was determined according to the method described by the Gelatin Manufacturers of Europe Monograph version 1 July 2000. Gelatin (7.5 g) was weighed into a Bloom jar (SCHOTTGLAS Mainz. Bloom test vessel, product no. 2112501) to which $105 \mathrm{ml}$ deionised water was added. The solution (6.67\%) was swirled with a glass rod, covered and allowed to stand at room temperature for $3 \mathrm{~h}$ to allow the gelatin to swell. The Bloom jars were then transferred and heated in a beaker of water at $60{ }^{\circ} \mathrm{C}$, on a magnetic heater stirrer for $20 \mathrm{~min}$ to dissolve the gelatin completely. The jar was covered and allowed to cool for $15 \mathrm{~min}$ at room 
temperature. Bloom jars were kept in a refrigerated water bath at $10 \pm 0.1^{\circ} \mathrm{C}$ over night $(16-18 \mathrm{~h})$ for gel maturation and tested on a TA-XT2 texture analyzer (Stable Microsystem, Godalming, $\mathrm{UK})$ by penetration with a standard radius cylinder $(\mathrm{P} / 0.5 \mathrm{R})$ probe, to a depth of $4 \mathrm{~mm}$ at $0.5 \mathrm{~mm} / \mathrm{s}$. The standard glass Bloom jar was placed centrally under the plunger and the maximum force reading (the resistance to penetration) was obtained and is the Bloom strength (g) of the gel. The analysis was undertaken in triplicate and bloom value of chicken skin gelatin was compared to that of a commercial bovine gelatin.

\subsubsection{Amino acid analysis}

\subsubsection{Preparation of samples and standards}

The amino acid content of chicken muscle hydrolysate was determined by the method of Bidlingmeyer et al., (1987); Badii and Howell, (2001) using HPLC (Waters: Alliance, Waters, UK, Hertfordshire, UK) with an integrated detector (Dual $\Lambda$ absorbance-Waters 2487) and separation module (Waters 2695). Chicken skin gelatin and commercial bovine gelatin were hydrolysed to yield free amino acids by placing $2.0 \mathrm{~g}$ of each sample in screw cap tubes with the addition of $15 \mathrm{ml} 6 \mathrm{~N} \mathrm{HCl}$. The tubes were then closed under nitrogen and heated in an oven at $110{ }^{\circ} \mathrm{C}$ for $24 \mathrm{~h}$. The hydrolysed samples and amino acid standards $(20 \mu \mathrm{l})$ were derivatized with phenylisothiocyanate (PITC) and analysed as described below.

\subsubsection{Derivatisation of amino acids with phenylisothiocyanate (PITC)}

Hydrolysed gelatin solution as well as amino acid standards $(20 \mu 1)$, were placed in tubes and dried under vacuum for $20 \mathrm{~min}$. Then, $20 \mu \mathrm{l}$ of drying solution containing $200 \mu \mathrm{l}$ methanol, $200 \mu \mathrm{l} 1 \mathrm{M}$ sodium acetate and $100 \mu \mathrm{l}$ triethylamine (TEA) (2:2:1), was added to the residues and the resulting solutions were vacuum-dried again for $10 \mathrm{~min}$. The derivatization reagent was freshly prepared by mixing $50 \mu \mathrm{l}$ PITC (kept at $-20{ }^{\circ} \mathrm{C}$, under nitrogen to prevent degradation), $350 \mu 1$ methanol (HPLC grade), $50 \mu 1$ TEA, and $50 \mu 1$ milli-Q water. The derivatization reagent $(20 \mu \mathrm{l})$ was added to each tube and the tubes were vortex-mixed and left at room temperature for 
$20 \mathrm{~min}$. The reagent was then removed under vacuum for $20 \mathrm{~min}$. The derivatized samples were vacuum-dried and dissolved in $100 \mu \mathrm{l}$ of sample buffer (Eluent A, prepared by dissolving $19 \mathrm{~g}$ of sodium acetate trihydrate in $1 \mathrm{~L}$ Milli-Q water, followed by the addition of $0.5 \mathrm{ml}$ TEA, adjusted to $\mathrm{pH} 6.4$ and filtered). To $940 \mathrm{ml}$ of this solution was added $60 \mathrm{ml}$ acetonitrile. The hydrolysed gelatin solutions as well as amino acids standards were analyzed, in triplicate, by HPLC.

\subsubsection{Small deformation oscillatory measurements}

Small deformation oscillatory measurements of different concentrations of chicken skin and bovine gelatin (3-10\% (w/v) in distilled water) were performed on a Rheometrics (Leatherhead, Surrey, UK) controlled stress 200 rheometer using $40 \mathrm{~mm}$ parallel plate geometry with a $0.3 \mathrm{~mm}$ gap. The sample was applied and silicone oil (Sigma cat. no 14615-3) was spread over the outer edge of the sample to prevent evaporation during heating using temperature sweeps and frequency sweeps. The two main parameters determined in a dynamic rheological test are the storage or elastic modulus $\left(G^{\prime}\right)$ describing the amount of energy that is stored elastically in the structure and the viscous or loss modulus $\left(\mathrm{G}^{\prime \prime}\right)$ indicating the amount of energy loss or the viscous response.

\subsubsection{Temperature sweeps}

A dynamic temperature sweep rheological test was used to determine the gelation and melting temperature of the gelatin samples. The stress and frequency used were $0.1 \mathrm{~Pa}$ and 1 $\mathrm{rad} / \mathrm{s}$ respectively. For gelation, the sample was initially maintained at a temperature of $40^{\circ} \mathrm{C}$ for $10 \mathrm{~min}$ to allow for equilibration. Gelatin samples were cooled on a Peltier plate from $40{ }^{\circ} \mathrm{C}$ to 10 ${ }^{\circ} \mathrm{C}$ and heated back to $40{ }^{\circ} \mathrm{C}$ both at a scanning rate of $2{ }^{\circ} \mathrm{C} / \mathrm{min}$. The gelation temperature was taken to be the temperature at which the elastic modulus began to dramatically increase in value. The temperature at which the $\mathrm{G}^{\prime} / \mathrm{G}^{\prime \prime}$ cross over occurred during cooling is close to the sol-gel transition or the gel formation point (Ross-Murphy, 1991; Gudmundsson, 2002). The test for determining melting temperature immediately followed after the gelation test. After the sample reached $10{ }^{\circ} \mathrm{C}$, the temperature was raised back to $40{ }^{\circ} \mathrm{C}$. Melting occurred when the elastic 
modulus $\left(G^{\prime}\right)$ began to decrease and loss modulus ( $\left.G^{\prime \prime}\right)$ began to increase in value. Changes in the elastic or storage modulus $\left(\mathrm{G}^{\prime}\right)$ and loss modulus $\left(\mathrm{G}^{\prime \prime}\right)$ were determined as a function of temperature and were recorded.

\subsubsection{Frequency sweeps}

A dynamic frequency sweep was performed at $10{ }^{\circ} \mathrm{C}$ to characterize the cross-linking behaviour of the gelatin. Stress was held at 319.7 $\mathrm{Pa}$ and frequency was oscillated from $0.1-100$ $\mathrm{rad} / \mathrm{s}$. All tests were performed within the identified linear viscoelastic region at the temperature tested. Changes in elastic $\left(\mathrm{G}^{\prime}\right)$ and loss modulus $\left(\mathrm{G}^{\prime \prime}\right)$ were obtained as a function of frequency and were recorded. Samples were measured at 3, 5, 7 and $10 \%(\mathrm{w} / \mathrm{v})$ concentration in triplicate.

\subsubsection{Differential scanning calorimetry (DSC) measurements}

Thermal properties of gelatin were investigated using a differential scanning calorimeter (DSC) VII (Setaram, Lyon, France). Samples and water as reference of approximately $500 \mathrm{mg}$ were weighed using a precision balance, Metler Toledo (AL 204), Mettler-Toledo Ltd., Beaumont Leys Leicester, UK., in a hermetic aluminium containers and scanned from 8 to $90{ }^{\circ} \mathrm{C}$ at a heating rate of $0.5{ }^{\circ} \mathrm{C} / \mathrm{min}$. Samples were measured at 3, 5, 7 and $10 \%$ (w/v) concentration. The helix-coil transition temperature $\left(T_{m}\right)$ was calculated as the temperature where the endothermic peak occurs. The temperature reached when half of the gelatin is denatured was measured as the tip of the peak. The total energy required for denaturing the protein, the enthalphy change $(\Delta H)$, was measured by integrating the area under the peak (Setaram DSC handbook and setsoft software). The endothermic peak was selected as the melting temperature of gelatin gels and the reading was the average of three determinations.

\subsubsection{FT-Raman spectroscopy}

For the Raman spectroscopy study, gelatin samples were examined in $7 \mathrm{ml}$ glass containers (FBG-Anchor, Cricklewood, London) on a Perkin-Elmer System 2000 FT-Raman spectrophotometer with excitation from a Nd:YAG laser at $1064 \mathrm{~nm}$. Frequency calibration of the 
instrument was performed using the sulphur line at $217 \mathrm{~cm}^{-1}$. Triplicate sets of the sample were prepared and analysed using laser power $1785 \mathrm{~mW}$. The spectra were an average of 125 scans which were baseline corrected and normalised to the intensity of the phenylalanine band at 1004 $\mathrm{cm}^{-1}$ (Howell et al., 1999; Badii \& Howell, 2003). The recorded spectra were analyzed using Grams 32 software (Galactic Industries Corp., Salem, NH). Bands in the spectra were assigned to the protein vibrational modes, based on the literature (Howell \& Saeed, 1999; Li-Chan, 1996; Badii \& Howell, 2002).

\subsubsection{Molecular weight by size-exclusion high-performance liquid chromatography (SE- HPLC) coupled to multi-angle laser light scattering (MALLS) and differential pressure viscometry (DPV)}

Analytical fractionation of the gelatins was carried out very kindly at the University of Nottingham by Prof S. Harding and Dr Gordon Morris, using two SE 7.8 x 300 mm columns (TTSK G6000PW and G4000PW, (Tosoh Bioscience, Tokyo, Japan) and protected by a similar 6 x $40 \mathrm{~mm}$ guard column. Chromatograms were acquired on-line with UV (Cecil 1100 series, Cambridge, UK), MALLS (DAWN HELEOS II, Wyatt Technology, Santa Barbara, CA), DPV (Viscostar II, Wyatt Technology) and differential refractive index (Optilab rEX, Wyatt Technology) sequentially placed detectors. The eluent (PBS) was pumped at $0.8 \mathrm{ml} \mathrm{min}^{-1}$ (the pump was PU-2080, Jasco Corporation, Great Dunmow, UK), and the samples were manually injected,100 $\mu \mathrm{l}$ for each sample, using a Beckman Altex 210A valve with a 50011 PEEK loop. Samples were centrifuged for $5 \mathrm{~min}$ at $10,000 \mathrm{x} \mathrm{g}$ before injection, and a $0.1 \mu \mathrm{m}$ on-line filter was placed after the columns was used to reduce particulate and improve the MALLS detectors' signal-to-noise ratio. The runs were made at room temperature $\left(28{ }^{\circ} \mathrm{C}\right)$, without thermostating of the columns and of the UV and MALLS cells (K5 type); the temperature was monitored and recorded by the ASTRA (Version 5.3.2.17) collection and analysis software (Wyatt Technology) controlling the DAWN HELEOS II, Viscostar II, and Optilab rEX instruments. The DPV capillaries and RI cell were kept at $20.0{ }^{\circ} \mathrm{C}$. Weight average molar masses $\langle\mathrm{M}\rangle_{\mathrm{w}}$, absolute rms (root mean square) $\mathrm{Z}$-average radii of gyration $\left(\left\langle\mathrm{R}_{\mathrm{g}}^{2}\right\rangle_{\mathrm{z}}\right)^{1 / 2}$, and weight-average intrinsic viscosities $\mathrm{h}[\mathrm{g}] \mathrm{iw}$ were calculated using the ASTRA software (Cardinali et al, 2010). 


\subsection{Statistical analysis}

Statistical tests were performed by using the SPSS package version 16 to analyze the data in this study. One way analysis of variance (ANOVA) was carried out. Differences between pairs of means were assessed on the basis of confidence intervals by using Least Significant Difference (LSD) test, followed by the t-test. The level of significance was considered at $(p<0.05)$.

\section{RESULTS AND DISCUSSION}

\subsection{Characterisation of extracted chicken skin gelatin}

\subsubsection{Extraction of gelatin}

The yield of extracted chicken skin gelatin was $16 \%$ based on dry weight basis (Table 1). However, the recovery values obtained based on the wet weight basis of this study (data not shown) was lower $(2.16 \%)$ compared to extracted fish gelatin (on a wet weight basis) which yielded $14 \%$ from cod skin (Gudmundsson \& Hafsteinsson, 1997), $7.81 \%$ and $5.39 \%$ yields of gelatin from red and black tilapia respectively (Jamilah \& Havinder, 2002), $14.3 \%$ and $7.25 \%$ yields from sin croaker and shortfin scad respectively (Cheow et al., 2007). These results indicated that the extraction procedure using a mixed acid and alkali process may not be optimal for chicken skin in terms of yield and improvements may be possible in future studies. The lower yield may be due to the loss of extracted collagen through leaching during the series of washing steps or due to the incomplete hydrolysis of the collagen (Jamilah \& Harvinder, 2002).

The aim of akali/acid pre-treatment is to weaken the collagen structure, solubilise the noncollagen proteins and hydrolyse some of the peptide bonds, but keeping the consistency of the collagen fibres (Ward \& Court, 1977). During the final step in the conversion of collagen to gelatin, the extraction temperature was $40-45{ }^{\circ} \mathrm{C}$ to achieve controlled partial hydrolysis of the cross-links and peptide bonds of the original collagen structure, and to obtain the ideal molecular weight distribution of gelatin. The yield at $50{ }^{\circ} \mathrm{C}$ is reported to be better than at $40{ }^{\circ} \mathrm{C}$ but the quality is lower (Cho et al., 2006). 


\subsubsection{Proximate composition of gelatin}

The proximate composition of chicken skin and bovine gelatin are presented in Table 1. The protein content of freeze-dried chicken skin gelatin was $80.76 \%$ while moisture and ash content was 9.81 and $0.37 \%$ respectively. The similarities in proximate composition between chicken skin and bovine skin thus relate to chicken skin being a potential alternative gelatine source.

\subsubsection{Gel strength}

Gel strength of chicken gelatin $(6.67 \%(\mathrm{w} / \mathrm{v})$ in distilled water) prepared in the present study provided significantly higher bloom value of $355 \pm 1.48 \mathrm{~g}$ compared with bovine gelatin $(229 \pm 0.71 \mathrm{~g})$ probably due to the intrinsic characteristics such as protein chain composition, molecular weight distribution, amino acid content and type of extraction treatment as well as the properties of collagen. Compared to other alternative sources like fish gelatin, chicken gelatin showed higher gel strength than for tilapia (181 $\mathrm{g}$ and $263 \mathrm{~g}$ bloom) as reported by Jamilah and Harvinder, (2002) and Grossman and Bergman (1992), respectively; horse mackerel (280 g bloom) by Badii and Howell (2006), sin croaker and shortfin scad (125 and $177 \mathrm{~g}$, respectively) by Cheow et al., (2007). The low hydroxyproline content of fish skin gelatin was a major reason for the low gel strength of the gelatin (Arnesen and Gildberg, 2002). It is well established that proline and hydroxyproline are responsible for the stability of the triple-helix of collagen structure through hydrogen bonding between free water molecules and hydroxyl group of the hydroxyproline in gelatin (Fernandez- Diaz et al., 2003; Badii and Howell, 2006). In addition, gelatin bloom strength is also dependent on other factors such as the chemical treatment of raw collagen materials, type and concentration of the gelatin and the time/temperature history of the sample (Babin \& Dickinson, 2001; Kolodziejska et al., 2004). Additionally, the higher bloom value contributes to the higher melting and gelling point and shorter gelling time of the final product. 


\subsection{Amino acid composition}

Table 2 presents the amino acid composition of chicken skin and bovine gelatin. As expected, glycine content was high, 33.70 and $37.05 \%$ for chicken skin and bovine gelatin, respectively. Imino acid Pro and hydroxyproline were higher for chicken gelatin (13.42\% and $12.13 \%$, respectively) compared with bovine gelatin (12.66 and $10.67 \%$ respectively). The higher content of the imino acids (Pro + H.Pro) and also Ala in chicken skin gelatin may contribute to its higher viscoelastic properties by promoting triple helix formation and stabilization of gelatin at low temperature.

\subsection{Rheological properties of gelatin gels}

\subsubsection{Temperature sweeps}

The gelling and melting temperatures and the dynamic viscoelastic profile of chicken and bovine gelatin at a concentration of $6.67 \%(\mathrm{w} / \mathrm{v})$ are presented in Table 3. The maximum values of elastic $\left(\mathrm{G}^{\prime}\right)$ and loss $\left(\mathrm{G}^{\prime \prime}\right)$ modulus of chicken gelatin (8273; $6639 \mathrm{~Pa}$, respectively) were significantly higher than for bovine gelatin (4330; 4122 Pa respectively) ( $<<0.05)$. Although the melting temperature of chicken gelatin $\left(33.57^{\circ} \mathrm{C}\right)$ was significantly higher $(\mathrm{p}<0.05)$ than that of bovine gelatin $\left(31.55^{\circ} \mathrm{C}\right)$, there was no significance difference $(p<0.05)$ for both chicken and bovine gelatin in the gelling temperature which was similar $\left(24^{\circ} \mathrm{C}\right)$.

Figures 1 and 2 compare the dynamic viscoelastic profile of chicken skin and bovine gelatin during both cooling from 40 to $10{ }^{\circ} \mathrm{C}$ and heating from 10 to $40{ }^{\circ} \mathrm{C}$ at constant rate of 2 ${ }^{\circ} \mathrm{C} /$ min. During cooling, G' values increased sharply due to an increase in the amount of energy that is elastically stored, which indicates rapid formation of junction zones and a strong reinforcement of the gel network. There was no significant difference $(p>0.05)$ for both chicken and bovine gelatin in the gelling temperature $\left(24^{\circ} \mathrm{C}\right)$. The gelling temperature is the temperature at which the $\mathrm{G}^{\prime} / \mathrm{G}^{\prime \prime}$ cross-over occurred on cooling and is close to the sol-gel transition (RossMurphy, 1991; Gudmundsson, 2002). 
Chicken gelatin showed higher elastic modulus $\left(G^{\prime}\right)$ values at low temperature indicative of enhanced ability to refold into a triple helix (Gomez Guillen et al., 2002). The higher elastic modulus $\left(G^{\prime}\right)$ of chicken gelatin showed that a higher thermal transition was required compared to the bovine gelatin both during cooling and heating, which indicates that it was more heat stable. These higher rheological properties and thermo-stability are typical of mammalian gelatin (Leunberger, 1991; Gilsenam and Ross-Murphy, 2000b) and are mainly related to imino acid composition, with hydroxyproline playing a unique role in stabilizing the triple helix. GomezGuillen et al., (2002) correlated the thermal stability of gelatin to the number and stability of Pro rich regions in collagen and gelatin molecules, which are high in mammalian species and fresh warm water fish (Kasankala et al., 2007).

\subsubsection{Effect of concentration on gelling and melting properties}

Figure 3 compares the effects of gelatin concentrations on the gelling temperature $\left({ }^{\circ} \mathrm{C}\right)$ of chicken and bovine gelatin during cooling. Gelling temperatures for both chicken and bovine gelatin were concentration $(3,5,7$ and $10 \%(w / v))$ dependent and increased with increase in concentration due to increased cross-linking by hydrogen bonding. Chicken gelatin showed higher gelling temperatures at all concentrations compared to bovine gelatin ( $\mathrm{p}<0.05)$. Gel formation $\left(\mathrm{G}^{\prime} / \mathrm{G}^{\prime \prime}\right.$ cross-over point) occurred at 21.02, 23.34, 24.44 and $27.19{ }^{\circ} \mathrm{C}$ for chicken gelatin and $18.47,21.40,22.85$ and $24.60{ }^{\circ} \mathrm{C}$ for bovine gelatin at $3,5,7$ and $10 \%(\mathrm{w} / \mathrm{v})$ gelatin in distilled water, respectively. The difference in the gelling ability of chicken compared with bovine gelatin may due to the intrinsic difference in the protein structure as well as the different pre-treatments used in gelatin production.

Similarly, chicken gelatin melted at a higher temperature $(p<0.05)$ than bovine gelatin as shown in Figure 4. The melting temperature of chicken $\left(32.67,32.82,33.53\right.$ and $\left.36.02{ }^{\circ} \mathrm{C}\right)$ and bovine $\left(30.03,30.68,31.35\right.$ and $\left.32.27^{\circ} \mathrm{C}\right)$ gelatin were obtained at $3,5,7$, and $10 \%(\mathrm{w} / \mathrm{v})$ gelatin

solutions respectively at $10-40{ }^{\circ} \mathrm{C}$. The melting temperatures of chicken gelatin were resulted from the decrease of storage modulus due to the loss of network structure. Previous studies (Gomez et al., 2002; Simon et al., 2003) showed that the concentration of helical structures 
decreased during melting. The difference in thermostability between chicken and bovine gelatin may be attributed to the difference in the proline and hydroxyproline content of each gelatin.

\subsubsection{Effect of concentration on frequency sweeps}

A dynamic rheological test at constant temperature $\left(10^{\circ} \mathrm{C}\right)$ was used to characterize the cross-linking behaviour of chicken (Figure 5) and bovine (Figure 6) gelatin at different concentrations $(3,5,7$ and $10 \%(\mathrm{w} / \mathrm{v}))$ respectively. At $10{ }^{\circ} \mathrm{C}$, both chicken and bovine gelatins reached their gelling point resulting in network formation and higher $G^{\prime}$ values. The linearly increasing storage modulus $\left(G^{\prime}\right)$ with frequency is indicative of a higher stability of the gel network in the given frequency range. The lower tan $\delta$ values obtained in this study (data not shown) during a frequency sweep is indicative of a good gel network (Hudson et al., 2000).

Fig 7 shows that the $\mathrm{G}^{\prime}$ values were higher than $\mathrm{G}^{\prime \prime}$ at all concentrations. The G' values for chicken gelatin were higher than those of bovine gelatin at all concentrations, indicating that the intermolecular interaction of bovine gelatin is weaker than that of chicken gelatin. Both chicken and bovine gelatin gels at a concentration of $3 \%(\mathrm{w} / \mathrm{v})$ showed a slight frequency dependence of G' (Figure 7 a), while at concentration 5, 7 and $10 \%(\mathrm{w} / \mathrm{v})$ gelatin gels were nearly independent of frequency for both chicken and bovine gelatin respectively (Figure $7 \mathrm{~b}, \mathrm{c}$ and d). This was in good agreement with the study of cod skin gelatin gels by Gilsenan and Ross-Murphy (2000a) which also showed a slight dependence of $G^{\prime}$ on frequency that became less obvious as the gelatin concentration increased. Increasing the protein concentration resulted in an increased storage modulus $\left(\mathrm{G}^{\prime}\right)$ as more energy from the deformation material was stored elastically in the gel network with an increased number of intermolecular cross-links thus resulting in a more integral matrix (Comfort \& Howell, 2002; Chiou et al., 2006).

\subsection{Differential scanning calorimetry (DSC)}

As shown in Figure 8, the DSC scans of chicken and bovine gelatin both showed a single endothermic peak. Melting temperature was observed from the maximum of the endothermic peak. The melting temperature of chicken gelatin was significantly higher than that of bovine 
gelatin gel $(\mathrm{p}<0.05)$. The lower melting temperature $\left(T_{m}\right)$ of bovine gelatin gel $\left(26.14{ }^{\circ} \mathrm{C}\right)$ compared to chicken gelatin gel $\left(31.18^{\circ} \mathrm{C}\right)$ indicates that the structural stability of bovine gelatin is weaker than that of chicken gelatin. Chicken gelatin had a higher enthalpy value $(0.42, \mathrm{~J} / \mathrm{g})$ than that of bovine gelatin $(0.36, \mathrm{~J} / \mathrm{g})$ (Table 4$)$. The stability of the collagen structure in chicken gelatin resulting in higher enthalpy values involves in the breakage of hydrogen bonds and helixcoil transition between the adjacent polypeptide chains of collagen molecules in the denaturation process.

\subsubsection{Effect of concentration on denaturation temperature of gelatin gel}

Table 4 compares the denaturation temperature $\left(T_{m}\right)$ and the enthalpy change $(\Delta H)$ of chicken skin and bovine gelatin solutions at concentrations of 3, 5, 7 and $10 \%(\mathrm{w} / \mathrm{v})$ in distilled water respectively. The denaturation temperatures of both gelatins increased with the increases in concentration. Chicken skin gelatin showed significantly higher values ( $p<0.05)$ of denaturation temperature compared to bovine gelatin at all concentrations. The denaturation temperature of chicken skin gelatin were $30.99 \pm 0.14,30.73 \pm 0.18,31.08 \pm 0.40$ and $31.16 \pm 0.35{ }^{\circ} \mathrm{C}$ while for bovine gelatin they were $25.91 \pm 0.53,25.97 \pm 1.25,26.41 \pm 0.41$ and $27.57 \pm 2.00{ }^{\circ} \mathrm{C}$ at $3,5,7$ and $10 \%(\mathrm{w} / \mathrm{v})$ concentration respectively. However, there was no significant difference ( $p>0.05)$ in the denaturation temperature between chicken skin and bovine gelatin at a concentration of $10 \%$. Similarly, the enthalpy change $(\Delta H)$ values of chicken skin gelatin were higher than the bovine gelatin at all concentration $(\mathrm{p}<0.05)$. The enthalpy change $(\Delta H)$ values of chicken gelatin were $0.36,0.50,0.60$ and $0.88 \mathrm{~J} / \mathrm{g}$ while for bovine gelatin they were $0.13,0.14$, 0.31 and $0.75 \mathrm{~J} / \mathrm{g}$ at $3,5,7$ and $10 \%(\mathrm{w} / \mathrm{v})$ concentration respectively. Results showed that the enthalpy change $(\Delta H)$ values of both gelatins increased with concentration increase. However there was no significant difference in $(\Delta H)$ values $(\mathrm{p}>0.05)$ between the concentration of 3 and 5 $\%$ for bovine gelatin. It is generally accepted that the endothermic process of collagenous materials involves rupture of hydrogen bonds and a rearrangement of the triple helix into a random configuration (Achet \& He, 1995; Tanioka et al., 1976). At high gelatin concentration, the junction zones concentration increases and the average distance between junction zones decreases and high energy is needed to break hydrogen bonds and for helix to coil transitions. 
The observed denaturation temperature of the gelatin gels was in the form of heat flow detected by DSC which corresponded to the energy absorbed by gelatin gels to achieve the helixto-coil conformation through melting of the junction zones (Michon et al., 1997), however the denaturation temperatures $\left(T_{m}\right)$ of chicken gelatin were only slightly affected by the gelatin concentration. In addition, the denaturation enthalpy depends on the imino acid content which is related to the stabilization of the collagen structure. The amino acid composition especially imino acids proline and hydroxyproline are believed to influence the rigidity of gelatin through hydrogen bonding that stabilizes the triple-helix structure (Norziah, et al., 2008, Badii \& Howell, 2006).

\subsection{Raman spectroscopy}

Table 5 shows the relative peak intensity of the spectral bands of chicken and bovine gelatin powders as mean \pm standard deviation of three replicates. The spectra (Figure not shown) were baseline corrected, smoothed and normalised to the intensity of the aromatic amino acid phenylalanine band at $1004 \mathrm{~cm}^{-1}$ which is not affected by the microenvironment or external factors $(\mathrm{Tu}, 1986)$. There was no significant difference $(\mathrm{p}>0.05)$ between bovine and chicken gelatin in the spectra which corresponds to the amino acid composition except for the band 990 $\mathrm{cm}^{-1}$ which indicated that chicken gelatin contained higher $\beta$ sheet-type structure compared to bovine gelatin $(\mathrm{p}<0.05)$.

Table 5 shows that the tyrosine doublet intensity ratio $\left(I_{855 /} I_{830}\right)$ of chicken gelatin $(0.87)$ was lower than bovine gelatin (0.92). The involvement of tyrosine residues in the gelation of gelatin was indicated by a decrease in the intensity ratio $I_{855 /} I_{830}$, which could be interpreted as an increase in the role of phenolic hydroxyl groups as strong hydrogen bond donor, or an increase in buriedness of the tyrosine residues within the gel network (Nonaka \& Li-Chan, 1993). The results obtained are in good agreement with previous research (Tu, 1986; Howell \& Li-Chan, 1996) as a high ratio $\left(I_{855 /} I_{830}\right)$ indicates that the tyrosine residue is exposed whereas a low ratio indicates strong hydrogen bonding. Therefore, evidence of stronger hydrogen bonding of chicken gelatin is reflected in the higher Bloom value compared to bovine gelatin. 
Besides the tyrosine doublet $\left(855\right.$ and $\left.830 \mathrm{~cm}^{-1}\right)$ and aliphatic hydrophobic $(\mathrm{C}-\mathrm{H}$ bending and $\mathrm{C}-\mathrm{H}$ stretching), information about protein tertiary structure is also provided by local environments such as tryptophan. The bands at 760 and $1554 \mathrm{~cm}^{-1}$ that correspond to the indole ring vibrations of the trytophan residues showed relative intensity values of $(0.21,0.22)$ and $(0.18,0.25)$ for chicken and bovine gelatin respectively. The buried or exposed state of tryptophan residue to the polar solvent or exposure of the tryptophan hydrophobic residues may decrease the tryptophan intensity of bands near $7601554 \mathrm{~cm}^{-1}$ bands.

Results for both gelatins showed strong bands at $1425 \mathrm{~cm}^{-1}$ which are 1.24 and 1.68 for chicken and bovine gelatin respectively $(\mathrm{p}<0.05)$. The band around $1425 \mathrm{~cm}^{-1}$ is assigned to the $\mathrm{COO}^{-}$symmetric stretch of the ionized carboxyl group vibration for aspartic and glutamic acid residues (shoulder) and side chain vibrations of the imidazole ring of histidine (Howell \& LiChan, 1996; Li-Chan \& Qin, 1998). Tu (1986) indicated that the carboxyl group vibrational bands can be used to monitor the state of ionization since the ionized group ( $\left.\mathrm{COO}^{-}\right)$exhibits a band at $1400-1420 \mathrm{~cm}^{-1}$ while the undissociated form $(\mathrm{COOH})$ exhibits bands at $1700-1750 \mathrm{~cm}^{-1}$.

$\mathrm{C}-\mathrm{H}$ deformation (bending and stretching) mode of aliphatic amino acids residues appear in the $1400-1500 \mathrm{~cm}^{-1}$ and $2800-3000 \mathrm{~cm}^{-1}$ region respectively. The intensity values of $\mathrm{CH}-$ bending at $1451 \mathrm{~cm}^{-1}$ which was assigned as an aliphatic hydrophobic $\left(\mathrm{CH}_{2}\right.$ and $\mathrm{CH}_{3}$ bending vibration) was 3.77 and 4.93 for chicken and bovine gelatin, respectively. Li-Chan et al., (1994) have reported that the changes in $\mathrm{C}-\mathrm{H}$ bending band intensity are a function of polarity of the solvent or microenvironment, suggesting its possible application to monitor hydrophobic interaction between aliphatic residues. The $\mathrm{C}-\mathrm{H}$ stretching vibrational bands of aliphatic amino acid residues at $2940 \mathrm{~cm}^{-1}\left(\mathrm{CH}_{2}\right.$ asymmetric stretching vibration) were 14.63 and 13.61 respectively for chicken and bovine gelatin which are not significantly different $(p>0.05)$. Similar to the C-H bending, a shift in the location of the $\mathrm{C}-\mathrm{H}$ stretching band near $2940 \mathrm{~cm}^{-1}$ to higher wavenumbers may suggest sensitivity of this band to the polarity of the microenvironment and to protein denaturation (Arteaga, 1994). There was no clear role of hydrophobic amino acids in the differences in the rheological properties of chicken and bovine gelatins in the present study. 
Moreover, the amide I and III bands are very useful for the investigation of secondary structure of the amide (peptide) bond of proteins with several distinct vibrational modes (Tu, 1986; Susi \& Byler, 1988; William, 1986). The Raman bands for amide $\mathrm{I}$ is $1645-1685 \mathrm{~cm}^{-1}$ and for amide III is $1200-1350 \mathrm{~cm}^{-1}$. The amide $\mathrm{I}$ band arises primarily from in-plane peptide $\mathrm{C}=\mathrm{O}$ stretching vibrations and partly from in-plane $\mathrm{N}-\mathrm{H}$ bending vibrations. The exact location of the amide I band in the Raman spectrum depends on hydrogen bonding and conformation of the polypeptide or protein molecule. Generally, proteins with high $\alpha$-helix, $\beta$-sheet, and random coil show an amide I band centred at $1645-1657 \mathrm{~cm}^{-1}, 1665-1680 \mathrm{~cm}^{-1}$ and $1660 \mathrm{~cm}^{-1}$ respectively. Amide I bands often shows several components or shoulders in the region because most proteins have mixed secondary structure (Li Chan et al., 1994; Ngarize et al., 2004). In this study however, most peaks were centred around $1660 \mathrm{~cm}^{-1}$; there was a significant difference $(p<0.05)$ between chicken (3.36) and bovine (3.90) gelatin (Table 5).

\subsection{Molecular weight analysis}

Chicken gelatin had a weight average molecular mass of 285,000 $\pm 31000 \mathrm{~g} / \mathrm{mol}$ which was

slightly lower but not significantly different from that of bovine gelatin which was 350,000 \pm $35000 \mathrm{~g} / \mathrm{mol}(p>0.05)$ (Table 6). Molecular weight of the extracted gelatin may be affected by the hydrolysis process that contributes to the splitting of the peptide bonds and also intramolecular crosslinks between peptide chains. There was no significant difference in the radius of gyration r_g $(\mathrm{nm})$ values between chicken gelatin $(32.8 \pm 1.3)$ and bovine gelatin $(33.5 \pm 2.4)(\mathrm{p}<0.05)$. Chicken gelatin exhibited higher viscosity values than bovine gelatin which were $150 \mathrm{ml} / \mathrm{g}$ and $127 \mathrm{ml} / \mathrm{g}$ for chicken and bovine gelatin respectively; this corresponds well with the higher bloom value, rheological properties of chicken skin gelatin compared with bovine gelatin. Generally, gelatins of higher gel strength show higher viscosity attributed to the higher proportion of cross-linked components ( $\beta$ - and $\gamma$-components) (Ogawa et al. 2004). In terms of stiffness/ flexibility, bovine gelatin had a Mark-Houwink "a" value of $0.69 \pm 0.02$ and chicken gelatin had a value of $0.83 \pm 0.02$; the higher the value the stiffer the molecule. In general terms $0.5-0.8$ is in the random coil range and greater than 0.8 is the rigid rod range, although triple helices would usually have a value of $>1$. (These preliminary results concur with the main rheological results that the chicken gelatin gel was stiffer than the bovine gelatin gel. 


\section{Conclusions}

Chicken gelatin from skin waste by-product can provide an alternative source of gelatin. as it shows similar chemical composition to bovine gelatin and better physicochemical properties compared with reported fish gelatins. The bloom strength of chicken gelatin $(355 \pm 1.48 \mathrm{~g})$ was significantly higher than bovine gelatin $(229 \pm 0.71 \mathrm{~g})$ but both formed stable structures on cooling. Chicken gelatin indicated higher gelling and melting properties, showing greater increases in the $\mathrm{G}^{\prime}, \mathrm{G}^{\prime \prime}$ and maximum values with increase in the concentration compared to bovine gelatin. The strength of gelatin gel, measured as a function of the frequency sweeps showed that $\mathrm{G}^{\prime}$ of chicken gelatin was higher than that of bovine gelatin at all concentrations tested and stable in the frequency range tested.

The higher DSC thermal transition values and higher enthalpy change $(\Delta H)$, on cooling and heating, shown by all concentrations of chicken gelatin compared with bovine gelatin, indicate that chicken gelatin was more heat stable probably due to the higher imino acids (Pro and H.Pro) content. FT-Raman analysis indicated a lower tyrosine doublet ratio and therefore more hydrogen bonding, as well as higher $\beta$-sheet type structure values, typical of stronger gels, by chicken gelatin compared with bovine gelatin. Both gelatins had high MW that was not significantly different; thus MW does not appear to be the main reason for differences in gel strength in this study. Although, the different origin and extraction processes can influence the properties of gelatins obtained, results from this study show that chicken skin gelatin has high potential to be an alternative to commercial gelatin.

\section{ACKNOWLEDGEMENTS}

The authors gratefully acknowledge funding received from the Malaysian Government for Norizah Mhd Sarbon's PhD studentship. We would also like to thank Professor Steve Harding and Dr Gordon Morris, University of Nottingham, Sutton Bonington for analysing the gelatin samples for molecular weight by SEC-MALLS and differential pressure viscometry. 


\section{REFERENCES}

Achet, D. \& He, X.W. (1995). Determination of the renaturation level in gelatin films. Polymer; (36): 787-791.

AOAC. (2006). Official methods of analysis of AOAC international (18 ${ }^{\text {th }}$ ed.). Virginia, USA: Association of Official and Analytical Chemists International.

Arnesen, J.A., \& Gildberg, A., (2002). Preparation and characterisation of gelatin from the skin of harp seal (Phoca groendlandica). Bioresource Tech. 82, 191-194.

Arnesen, J. A., \& Gildberg, A. (2007). Extraction and characterization of gelatin from Atlantic salmon (Salmo salar) skin. Bioresource Technology, 98, 53-57.

Arteaga, G.E. (1994). Assessment of protein surface hydro-phobicity by spectroscopic methods and its relation to emulsifying properties of proteins. In: Ph.D. thesis, Department of Food Science, The University of British Columbia, Vancouver, B. C., Canada.

Babin, H., \& Dickinson, E. (2001). Influence of transglutaminase treatment on the thermoreversible gelation of gelatin. Food Hydocolloids, 15(3), 271-276.

Badii, F., \& Howell, N. K. (2002). Changes in the texture and structure of cod (Gadus morhua) and haddock (Melanogrammus aeglefinus) during frozen storage. Journal of Science of Food and Agriculture, 82 87-97.

Badii, F., \& Howell, N. K. (2003). Elucidation of the effect of formaldehyde and lipids on frozen stored cod collagen by FT-Raman spectroscopy and differential scanning calorimetry. J. Agric. Food Chem. 51, 1440-1446

Badii, F., \& Howell, N. K. (2006). Fish gelatin: Structure, gelling properties and interaction with egg albumen proteins. Food Hydrocolloids, 20, 630-640.

Binsi, P.K., Shamasundara, B.A., Dileepa, A.O., Badii, F., \& Howell, N.K. (2009). Rheological and functional properties of gelatin from the skin of Bigeye snapper (Priacanthus hamrur) fish: Influence of gelatin on the gel-forming ability of fish mince. Food Hydrocolloids 23, 132-145.

British Standard Institution (BSI), (1975). Methods for sampling and testing gelatins (physical and chemical methods).London:BSI.

Cardinali, B., Profumo, A., Aprile, A., Byron, O., Morris, G., Harding, S.E., Stafford, W.F. \& Rocco, M. (2010). Hydrodynamic and mass spectrometry analysis of nearly-intact human fibrinogen, chicken fibrinogen, and of a substantially monodisperse human fibrinogen fragment X. Archives of Biochemistry and Biophysics, 493, 157-168. 
Cheow, C.S., Norizah, M.S., Kyaw, Z.Y., \& Howell, N.K. (2007). Preparation and characterisation of gelatins from the skins of sin croaker (Johnius dussumieri)and shortfin scad (Decapterus macrosoma). Food Chemistry, 101(2007), 386-391.

Chiou, B.S., Avena-Bustillos, R.J., Shey, J., Yee, E., Bechtel, P.J., Imam, S.H., Glenn, G.M. \& Orts, W.J. (2006). Rheological and mechanical properties of cross-linked fish gelatins. Polymer 47, 6379-6386.

Choi, S.S., \& Regenstein, J.M. (2000). Physico-chemical and sensory characteristics of fish gelatin. Journal of Food Science, 65, 194-199.

Cho, S., Jahncke, M.L., Chin, K., \& Eun, J. (2006). The effect of processing conditions on the properties of gelatin from skate (Raja Kenojei) skins. Food Hydrocolloids, 20(6), 810-816.

Comfort, S., \& Howell, N.K. (2002). Gelation properties of soya and whey protein isolate mixtures. Food Hyrocolloids, 16, 661-672.

Fernandez-Diaz, M.D., Gomez-Guillen, M.C., \& Montero, P., (2003). Effect of freezing fish skin on molecular and rheological properties of extracted gelatine. Food Hydrocoll 17, 281-286.

Gelatin Manufacturers of Europe (GME), (2000). Standardised methods for the testing of edible gelatin. Gelatin Monograph, version July 2000.

Gilsenan, P.M., \& Ross-Murphy, S.B. (2000a). Rheological characterisation of gelatins from mammalian and marine sources. Food Hydrocolloids, 14, 191-195.

Gilsenan, P.M., \& Ross-Murphy, S.B. (2000b). Viscoelasticity of thermoreversible gelatin gels from mammalian and piscine collagens. Journal of Rheology, 44(4), 871-883.

Go’ mez-Guille’ n, M.C., Turnay, J., Fernandez-Diaz, M. D., Ulmo, N., Lizarbe, M. A., \& Montero, P. (2002). Structural and physical properties of gelatin extracted from different marine species: a comparative study. Food Hydrocolloids, 16, 25-34.

Gudmundsson. (2002). Rheological properties of fish gelatin. Journal of Food Science, 67, 21722176.

Gudmundsson, M. \& Hafsteinsson, H. (1997). Gelation from cod skins as affected by chemical treatments. J. Food Sci., 62, 37-47.

Grossman, S., \& Bergman, M., (1992). Process for the production of gelatin from the fish skins. US Patent 5,093,474. 
Howell, N.K., Arteaga, G., Nakai, S., \& Li-Chan, E.C.Y. (1999). Raman spectral analysis in the $\mathrm{C}-\mathrm{H}$ stretching region of proteins and amino acids for investigation of hydrophobic interactions. J. Agric. Food Chem. 1999, 47, 924-933.

Howell, N. K., \& Li-Chan, E. C. Y. (1996). Elucidation of interactions of lysozyme with whey proteins by Raman spectroscopy. International Journal of Food Science and Technology, 31, 439-451.

Howell, N.K. \& Saeed, S. (1999). The effect of antioxidants on the production of lipid oxidation products and transfer of free radicals in oxidised lipid-protein systems. In: Antioxidants in Human Health and Disease (Chapter 4) (edited by T.K. Basu, N.J. Temple \& M.L. Garg). Pp. 4354. Wallingford: CABI Publishers.

Hudson, H.M., Daubert, C.R. \& Foegeding, E.A. (2000). Rheological and physical properties of derivatized whey protein isolate powders. Journal of Agricultural and Food Chemistry, 48, 3112-3119.

Jamilah, B., \& Harvinder, K. G. (2002). Properties of gelatins from skins of fish-black tilapia (Oreochromis mossambicus) and red tilapia (Oreochromis nilotica). Food Chemistry, 77, 81-84.

Johnston-Banks, F. A. (1990). Gelatine. In P. Harris (Ed.), Food gels (pp. 233-285). London: Elsevier Applied Science.

Jun, M., Lee, J.M., Lee, K.S., \& Kim, K.O. (2000). The effect of preparation conditions on the properties of Jokpyun (traditional Korean gel type food) model system. Food Science and Biotechnology, 9(27), 27-31.

Karim, A.A. \& Bhat, R. (2009). Fish gelatin: properties, challenges, and prospects as an alternative to mammalian gelatins, Food Hydrocolloids 23, 563-576.

Kasankala, L. M., Xue, Y., Weilong, Y., Hong, S. D., \& He, Q. (2007). Optimization of gelatine extraction from grass carp (Catenopharyngodon idella) fish skin by response surface methodology. Bioresource Technology, 98, 3338-3343.

Kolodziejska, I., Kaczorowski, K., Piotrowska, B., \& Sadowska, M., (2004). Modification of the properties of gelatine from skins of Baltic cod (Gadus morhua) with transglutaminase. Food Chem. 86, 203-209.

Leuenberger, B.H. (1991). Investigations of viscosity and gelation properties of different mammalian and fish gelatins. Food Hydrocolloids 5:353-361.

Li-Chan, E., \& Qin, L. (1998). Application of Raman spectroscopy to the structural analysis of food protein networks. In D. J. Sessa, and J. L. Willett (Eds.), Paradigm for successful utilisation of renewable resources (pp. 123-137). Illinois, USA: AOCS Press. 
Li-Chan, E., Nakai, S., and Hirotsuka, M. (1994). Raman spectroscopy as a probe of protein structure in food systems. Ch.8. In Protein Structure-Function Relationships in Foods, R.Y.Yada, R.L., Jackman and J.L. Smith (Eds.) p. 163-197. Blackie Academic \& Profesional, Chapman \& Hall Inc., London, England.

Lim, J.Y., Oh, S.S., \& Kim, K.O. (2001). The effects of processing conditions on the properties of chicken feet gelatin. Food Science and Biotechnology, 10(6), 638-645.

Michon, C., Cuvelier, G., Launay, B., \& Parker, A. (1997). Interactions in mixture of gelatin and i-carrageenan. In E. Dickinson and B. Bergenstahl, Food colloids. Proteins, lipids and polysaccharides (pp. 316-325). Cambridge: The Royal Society of Chemistry.

McClements, D.J. (2005). Food emulsions: Principles, practice and techniques. Boca Raton, FL:CRC Press.

Morrison, N. A., Clark, R. C., Chen, Y. L., Talashek, T., \& Sworn, G. (1999). Gelatin alternatives for the food industry. In K. Nishinari, F. Kremer, and G. Lagaly (Eds.), Physical chemistry and industrial application of gellan gum (pp. 127e131). Heidelberg: Springer Verlag.

Ngarize, S., Adams, A., \& Howell, N. (2004). Studies on egg albumen and whey protein interactions by FT-Raman spectroscopy and rheology. Food Hydrocolloids, 18, 49-59.

Nonaka, M. \& Li-Chan, E. (1993). Raman spectroscopic study of thermally induced gelation of whey proteins. Journal of Agricultural Food Chemistry, 41, 1176-1181.

Norziah, M.H., Al-Hassan, A., Khairulnizam, A.B., Mordi, M.N. \&Norita M. (2008). Characterization of fish gelatin from surimi processing wastes: Thermal analysis and effect of transglutaminase on gel properties. Food Hydrocolloids, 23, 1610-1616.

Ogawa, M., Portier, R.J., Moody, M.W., Bell, J., Schexnayder, M.A. \& Losso J.N. (2004). Biochemical properties of bone and scale collagens isolated from the subtropical fish black drum (Pogonia cromis) and sheepshead seabream (Archosargus probatocephalus), Food Chemistry 88, 495-501.

Ross-Murphy, S. B. (1991). Incipient behaviour of gelatin gels. Rheologica Acta, 30, 401-411. Rother, J. (1995). Edible gelatin types, use and application in the food industry. Food Technology Europe, 32-42.

Simon, A., Grohens, Y., Vandanjon, L., Bourseau, P., Balnois, E., \& Levesque, G. (2003). A comparative study of the rheological and structural properties of gelatin gels of mammalian and fish origins. Macromolecular Symposia, 203, 331-338.

Susi, H. \& Byler, D.M. (1988) 'Fourier Deconvolution of the amide I Raman band of proteins as related to conformation’ in Appl. Spectrosc. 42, 819-826 
Tanioka, A., Miyasaka, K. \& Ishikawa, K. (1976). Reconstitution of collagen fold structure with stretching gelatin film. Biopolymers; (15): 1505-1511.

Tu, A.T. (1986). Peptide backbone conformat ion and microenvironment of protein side-chains. In R. J. H. Clark, \& R. E. Hester (Eds.), Spectroscopy of biological systems (pp. 47-112). New York: Wiley.

Ward, A.G. \& A. Courts, (1977). The science and technology of gelatin. London: Academic Press inc. LTd.

Williams, R.W. (1986). 'Protein secondary structure analysis using Raman amide I and amide IIISpectra' in Methods Enzymol. 130, 311-331.

Yang, H., Wang, Y., Jiang, M., Oh, J. H., Herring, J., \& Zhou, P. (2007). 2-step optimization of the extraction and subsequent physical properties of channel catfish (Ictalurus punctatus) skin gelatin. Journal of Food Science, 72, C188-C195.

Zhou, P., Mulvaney, S. J., \& Regenstein, J. M. (2006). Properties of Alaska pollock skin gelatin: a comparison with Tilapia and pork skin gelatins. Journal of Food Science, 71, C313-C321. 
Table 1 Proximate composition of chicken skin and bovine gelatin

\begin{tabular}{ccc}
\hline Composition & $\begin{array}{c}\text { Chicken } \\
\text { skin gelatin }(\boldsymbol{\%})\end{array}$ & $\begin{array}{c}\text { Bovine } \\
\text { gelatin }(\boldsymbol{\%})\end{array}$ \\
\hline Yield & $16 \% \pm 0.91$ & - \\
Moisture & $9.81 \pm 0.05$ & $9.68 \pm 0.06$ \\
Protein & $80.76 \pm 0.30$ & $81.75 \pm 0.50$ \\
Ash & $0.37 \pm 0.02$ & $1.06 \pm 0.00$ \\
\hline
\end{tabular}

Values are the means \pm standard deviation of three replicates.

Table 2 Amino acid composition of chicken skin and bovine gelatin

\begin{tabular}{|ccc|}
\hline Amino acids & $\begin{array}{c}\text { Chicken skin gelatin } \\
(\boldsymbol{\%})\end{array}$ & $\begin{array}{c}\text { Bovine gelatin } \\
(\boldsymbol{\%})\end{array}$ \\
\hline Asp & $2.11 \pm 0.02$ & $3.29 \pm 0.01$ \\
\hline Glu & $5.84 \pm 0.01$ & $5.43 \pm 0.03$ \\
\hline H.Pro & $12.13 \pm 0.02$ & $10.67 \pm 0.11$ \\
Ser & $2.20 \pm 0.00$ & $2.93 \pm 0.08$ \\
\hline Gly & $33.70 \pm 0.02$ & $37.05 \pm 0.11$ \\
\hline His & $0.30 \pm 0.01$ & - \\
\hline Arg & $5.57 \pm 0.00$ & $5.09 \pm 0.04$ \\
\hline Thr & $1.01 \pm 0.00$ & $0.82 \pm 0.03$ \\
\hline Ala & $10.08 \pm 0.02$ & $8.41 \pm 0.10$ \\
\hline Pro & $13.42 \pm 0.01$ & $12.66 \pm 0.14$ \\
\hline Tyr & $1.22 \pm 0.01$ & $1.16 \pm 0.01$ \\
\hline Val & $1.94 \pm 0.02$ & $2.07 \pm 0.02$ \\
\hline Met & $0.07 \pm 0.00$ & $0.22 \pm 0.13$ \\
\hline Cys & $0.16 \pm 0.00$ & $0.47 \pm 0.00$ \\
\hline Ileu & $1.15 \pm 0.00$ & $1.01 \pm 0.01$ \\
\hline Leu & $2.63 \pm 0.00$ & $1.89 \pm 0.01$ \\
\hline Phe & $1.77 \pm 0.00$ & $1.60 \pm 0.02$ \\
\hline Trp & $0.04 \pm 0.00$ & $0.48 \pm 0.00$ \\
\hline Lys & $4.66 \pm 0.00$ & $4.86 \pm 0.05$ \\
\hline
\end{tabular}

Values are means \pm SD of three determinations. 
Table 3. Rheological properties of $6.67 \%(\mathrm{w} / \mathrm{v})$ chicken and bovine gelatin including gelling and melting temperature, and elastic $\left(G^{\prime}\right)$ and loss $\left(G^{\prime \prime}\right)$ modulus values after heating to $40^{\circ} \mathrm{C}$ and cooling to $10^{\circ} \mathrm{C}$.

\begin{tabular}{|l|c|c|c|c|}
\hline Gelatin & $\begin{array}{c}\text { Gelling } \\
\text { Temp. }\left({ }^{\circ} \mathrm{C}\right)\end{array}$ & $\begin{array}{c}\text { Melting } \\
\text { Temp. }\left({ }^{\circ} \mathrm{C}\right)\end{array}$ & \multicolumn{2}{|c|}{ Maximum value after cooling } \\
\hline $6.67(\%)$ & & & $\mathrm{G}^{\prime}[\mathrm{Pa}]$ & $\mathrm{G}^{\prime \prime}[\mathrm{Pa}]$ \\
\hline Chicken & $24.88 \pm 0.27 \mathrm{a}$ & $33.57 \pm 0.52 \mathrm{a}$ & $8273 \pm 1016 \mathrm{a}$ & $6639 \pm 1192 \mathrm{a}$ \\
\hline Bovine & $24.43 \pm 0.91 \mathrm{a}$ & $31.55 \pm 0.04 \mathrm{~b}$ & $4330 \pm 31 \mathrm{~b}$ & $4121 \pm 59 \mathrm{~b}$ \\
\hline
\end{tabular}

Values are means \pm SD of three determinations.

$\mathrm{a}-\mathrm{b}$ Mean within a row with different letters are significantly difference $(p<0.05)$.

Table 4: Denaturation temperature $\left(T_{\mathrm{m}}\right)$ and enthalpy value $(\Delta H)$ of chicken and bovine gelatin at different concentrations in distilled water.

\begin{tabular}{|c|c|c|c|c|}
\hline Conc. (\%) & \multicolumn{2}{|c|}{$T_{\mathbf{m}}\left({ }^{\circ} \mathbf{C}\right)$} & \multicolumn{2}{c|}{ Enthalpy $(\Delta H, J / g)$} \\
\hline & Chicken & Bovine & Chicken & Bovine \\
\hline 10 & $31.16 \pm 0.35_{\mathrm{a}}$ & $27.57 \pm 2.00_{\mathrm{a}}$ & $0.88 \pm 0.05_{\mathrm{aA}}$ & $0.75 \pm 0.00_{\mathrm{cB}}$ \\
\hline 7 & $31.08 \pm 0.40_{\mathrm{a}}$ & $26.41 \pm 0.41_{\mathrm{b}}$ & $0.60 \pm 0.02_{\mathrm{bA}}$ & $0.31 \pm 0.02_{\mathrm{bB}}$ \\
\hline 5 & $30.73 \pm 0.18_{\mathrm{a}}$ & $25.97 \pm 1.25_{\mathrm{b}}$ & $0.50 \pm 0.01_{\mathrm{cA}}$ & $0.14 \pm 0.03_{\mathrm{aB}}$ \\
\hline 3 & $30.99 \pm 0.14_{\mathrm{a}}$ & $25.91 \pm 0.53_{\mathrm{b}}$ & $0.36 \pm 0.01_{\mathrm{dA}}$ & $0.13 \pm 0.01_{\mathrm{aB}}$ \\
\hline
\end{tabular}

Each value is a mean of triplicate determinations and is reported with its standard deviation. a-b Means within a column with different letters are significantly different $(p<0.05)$ on $T_{\mathrm{m}}$ and a-d Means within a row with different letters are significantly different $(p<0.05)$ on $\Delta H$ and A-B Means within a column with different letters are significantly different $(p<0.05)$ on $\Delta H$. Analyses were carried out by using ANOVA followed by LSD test. 
Table 5. Relative peak intensity of Raman spectra of chicken and bovine gelatin.

\begin{tabular}{lcc}
\hline Peak assignment (wavenumbers $\left(\mathrm{cm}^{-1}\right)$ & \multicolumn{2}{c}{ Relative peak intensity of gelatin } \\
\hline & Chicken & Bovine \\
Trp (760) & $0.21 \pm 0.02_{\mathrm{a}}$ & $0.22 \pm 0.03_{\mathrm{a}}$ \\
Tyr (830) & $0.82 \pm 0.08_{\mathrm{a}}$ & $0.98 \pm 0.06_{\mathrm{a}}$ \\
Tyr (855) & $0.72 \pm 0.05_{\mathrm{a}}$ & $0.91 \pm 0.04_{\mathrm{a}}$ \\
Tyr (855/830) & $0.87 \pm 0.05_{\mathrm{a}}$ & $0.92^{\mathrm{a}} \pm 0.01_{\mathrm{a}}$ \\
$\alpha$-Helix C-C Stretch, $\mathrm{CH}_{3}$ symmetric stretch (920) & $1.02 \pm 0.03_{\mathrm{a}}$ & $1.36 \pm 0.02_{\mathrm{a}}$ \\
$\beta$-Sheet like structure (990) & $0.07 \pm 0.00_{\mathrm{a}}$ & $0.02 \pm 0.00_{\mathrm{b}}$ \\
Phe, ring band (1034) & $0.76 \pm 0.02_{\mathrm{a}}$ & $0.90 \pm 0.11_{\mathrm{a}}$ \\
Isopropyl anti symmetric stretch CH stretch back bone & $0.25 \pm 0.04_{\mathrm{a}}$ & $0.25 \pm 0.01_{\mathrm{a}}$ \\
(1128) & & \\
CH3 anti symmetric (aliphatic), CH3 rock (aromatic) (1160) & $0.53 \pm 0.08_{\mathrm{a}}$ & $0.65 \pm 0.05_{\mathrm{a}}$ \\
Amide III - $\beta$-Sheet type structure (1239) & $2.55 \pm 0.20_{\mathrm{a}}$ & $3.20 \pm 0.10_{\mathrm{a}}$ \\
Amide II (1320) & $1.43 \pm 0.19_{\mathrm{a}}$ & $1.86 \pm 0.05_{\mathrm{a}}$ \\
H band doublet from Trp (1340) & $0.94 \pm 0.14_{\mathrm{a}}$ & $1.36 \pm 0.05_{\mathrm{a}}$ \\
(Sh*, residue vibration) asp, glu, lys (1425) & $1.24 \pm 0.03_{\mathrm{a}}$ & $1.68 \pm 0.03_{\mathrm{b}}$ \\
Aliphatic groups CH bend (1451) & $3.77 \pm 0.22_{\mathrm{a}}$ & $4.93 \pm 0.15_{\mathrm{b}}$ \\
Trp (1554) & $0.18 \pm 0.02_{\mathrm{a}}$ & $0.25 \pm 0.07_{\mathrm{a}}$ \\
Amide I (1660) & $3.36 \pm 0.18_{\mathrm{a}}$ & $3.90 \pm 0.14_{\mathrm{a}}$ \\
CH stretch, aliphatic (2940) & $14.63 \pm 1.06_{\mathrm{a}}$ & $13.61 \pm 0.42_{\mathrm{a}}$ \\
shoulder (2888) & $5.49 \pm 0.34_{\mathrm{a}}$ & $4.97 \pm 0.15_{\mathrm{a}}$ \\
shoulder (2976) (2969) & $9.48 \pm 0.73_{\mathrm{a}}$ & $8.84 \pm 0.29_{\mathrm{a}}$
\end{tabular}

Each value is a mean of three replicate determinations and is reported with its standard deviation. $\mathrm{a}-\mathrm{b}$ Means within a column with different letters are significantly different $(p<0.05)$.

Sh* Shoulder.

Table 6. Weight average molecular mass $\langle\mathrm{M}\rangle_{\mathrm{w}}$, intrinsic viscosity [ $\eta$ and radius of gyration r_g (nm) of extracted chicken skin gelatin compared to bovine gelatin.

\begin{tabular}{|cccc|}
\hline Gelatin & Mw (g/mol) & {$[\eta](\mathrm{ml} / \mathrm{g})$} & r_g $(\mathrm{nm})$ \\
\hline Chicken skin & $285,000 \pm 31000$ & $150 \pm 18$ & $32.8 \pm 1.3$ \\
\hline Bovine & $350,000 \pm 35000$ & $127 \pm 9$ & $33.5 \pm 2.4$ \\
\hline
\end{tabular}

Each value is a mean of three replicate determinations and is reported with its standard deviation. 


\section{$\underline{\text { List of figure headings }}$}

Figure 1. Viscoelastic properties upon cooling and heating of gelatin preparations. Changes in $\mathrm{G}^{\prime}$ and $\mathrm{G}^{\prime \prime}$ values of bovine gelatin $(6.67 \%)$ were monitored during cooling from 40 to $10^{\circ} \mathrm{C}$ and subsequent heating from 10 to $40^{\circ} \mathrm{C}$.

Figure 2. Viscoelastic properties upon cooling and heating of gelatin preparations. Changes in $\mathrm{G}^{\prime}$ and $\mathrm{G}^{\prime \prime}$ values of chicken gelatin $(6.67 \%)$ were monitored during cooling from 40 to $10^{\circ} \mathrm{C}$ and subsequent heating from 10 to $40^{\circ} \mathrm{C}$.

Figure 3. The effect of gelatin concentration on the gelling temperature $\left({ }^{\circ} \mathrm{C}\right)$ of bovine and chicken gelatin during cooling from 40 to $10^{\circ} \mathrm{C}$.

Figure 4. The effect of gelatin concentrations on the melting temperature $\left({ }^{\circ} \mathrm{C}\right)$ of a) bovine and b) chicken gelatin during heating from 10 to $40^{\circ} \mathrm{C}$.

Figure 5. Elastic modulus $\left(\mathrm{G}^{\prime}\right)$ in the frequency sweep of different concentrations $(3,5,7$ and10\% $(\mathrm{w} / \mathrm{v}))$ of chicken gelatin at $10^{\circ} \mathrm{C}$.

Figure 6. Elastic modulus $\left(\mathrm{G}^{\prime}\right)$ in the frequency sweep with different concentrations $(3,5,7$ and $10 \%(\mathrm{w} / \mathrm{v}))$ of bovine gelatin at $10^{\circ} \mathrm{C}$.

Figure 7. Dynamic storage $\left(\mathrm{G}^{\prime}\right)$ and loss $\left(\mathrm{G}^{\prime \prime}\right)$ modulus in frequency sweeps of bovine (BG) and chicken gelatin (CG) with various concentrations: a) $3 \%$, b) $5 \%$, c) $7 \%$ and d) $10 \%$ (w/v).

Figure 8. DSC thermogram of denaturation temperature for bovine and chicken gelatin at concentration of $6.67 \%$ which heated from 10 to $90{ }^{\circ} \mathrm{C}$. 
Figure 1

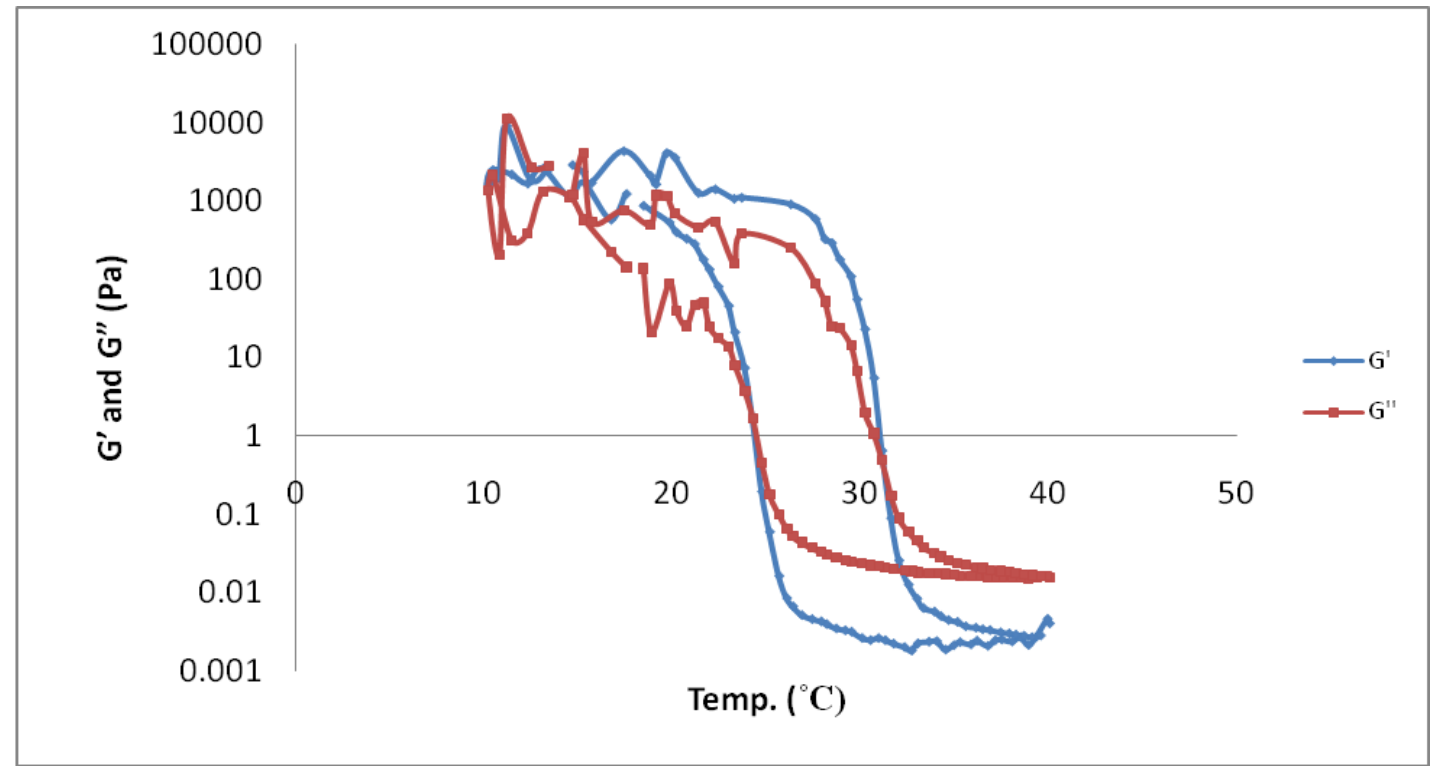

Figure 2

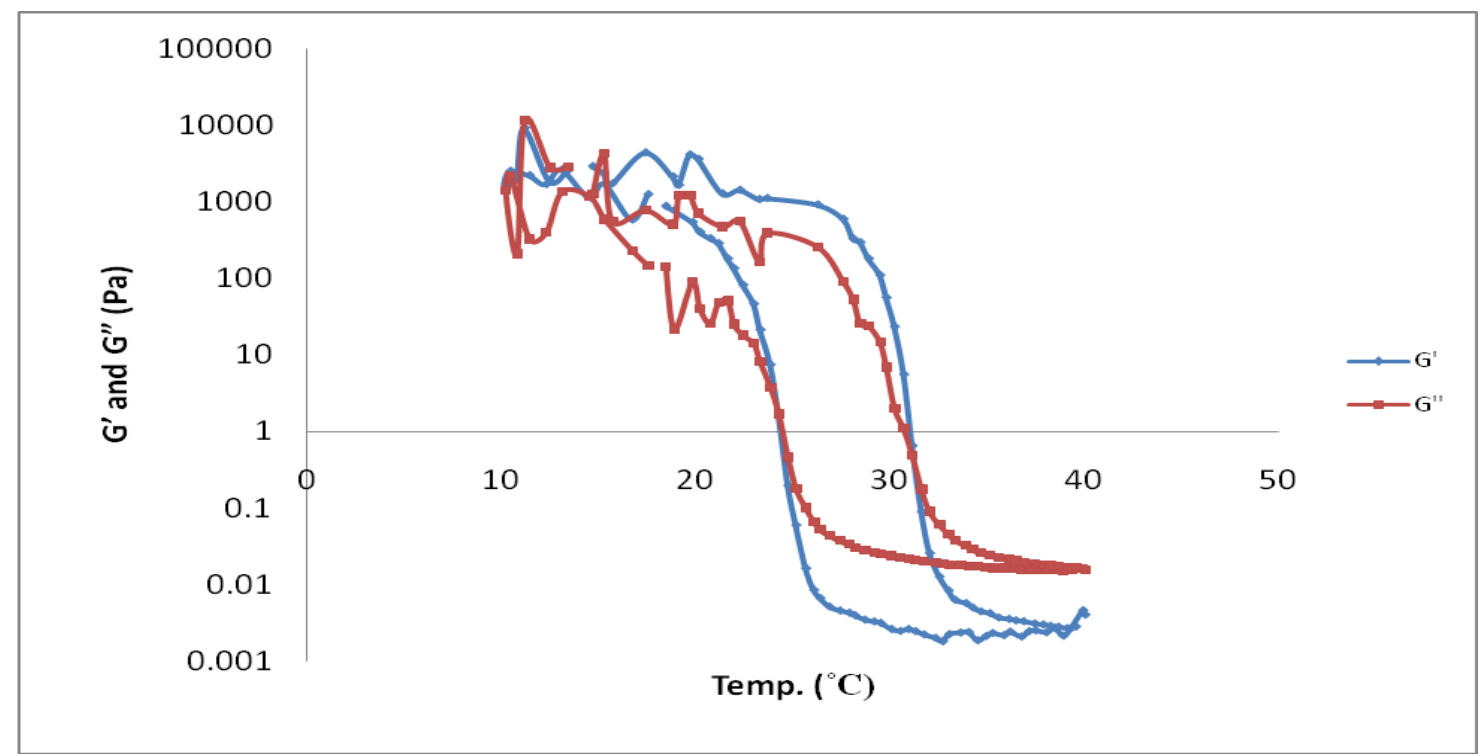


Figure 3

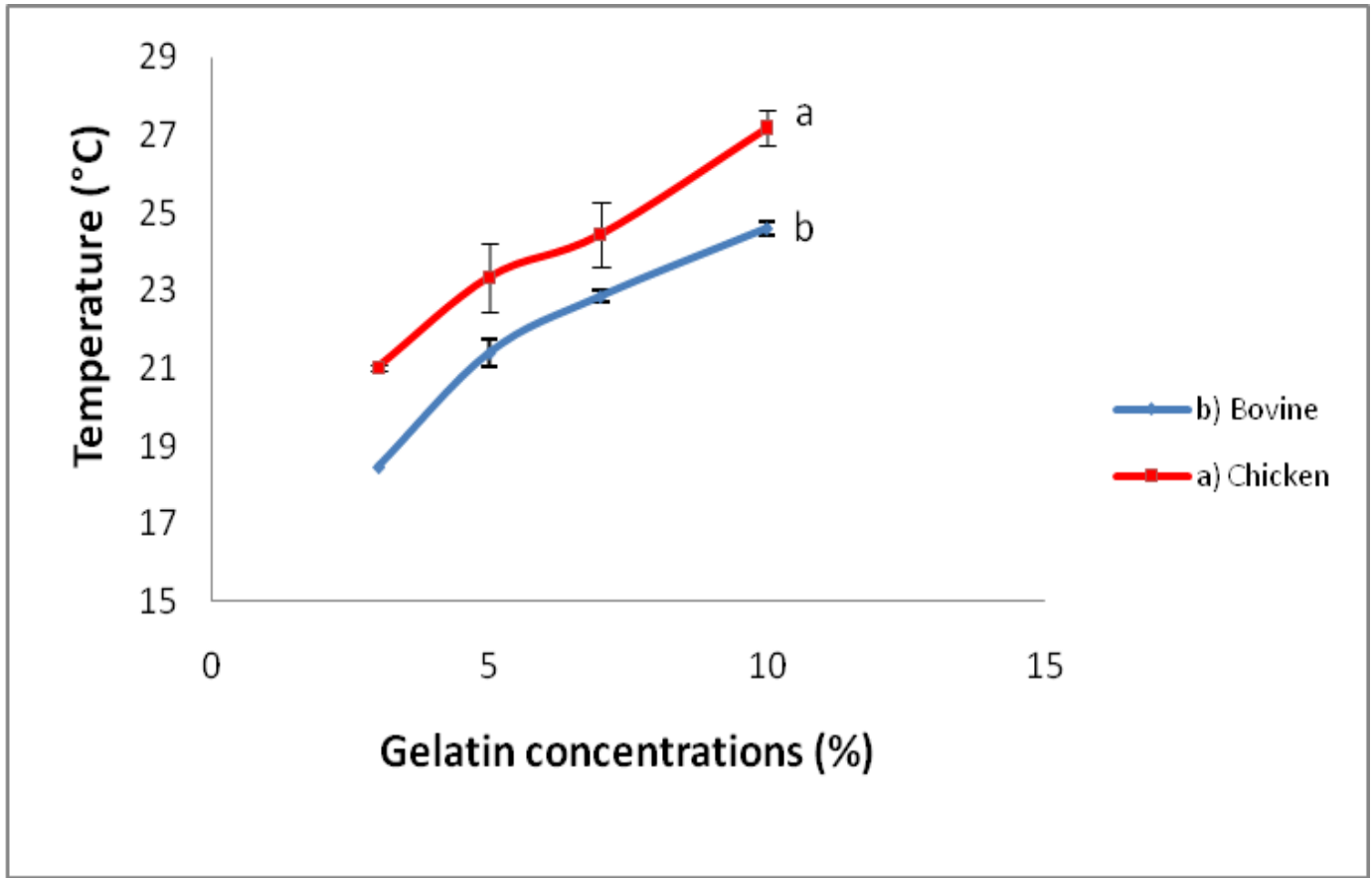

Figure 4

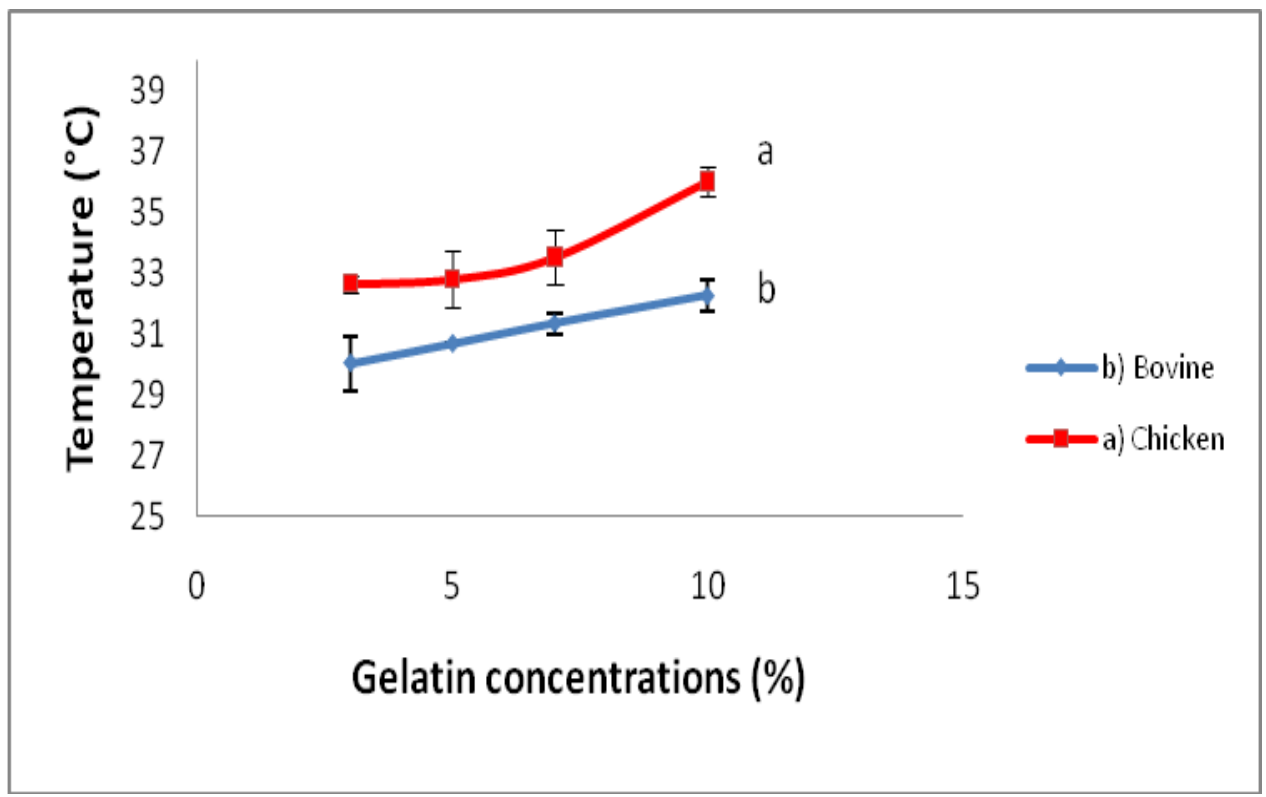


Figure 5

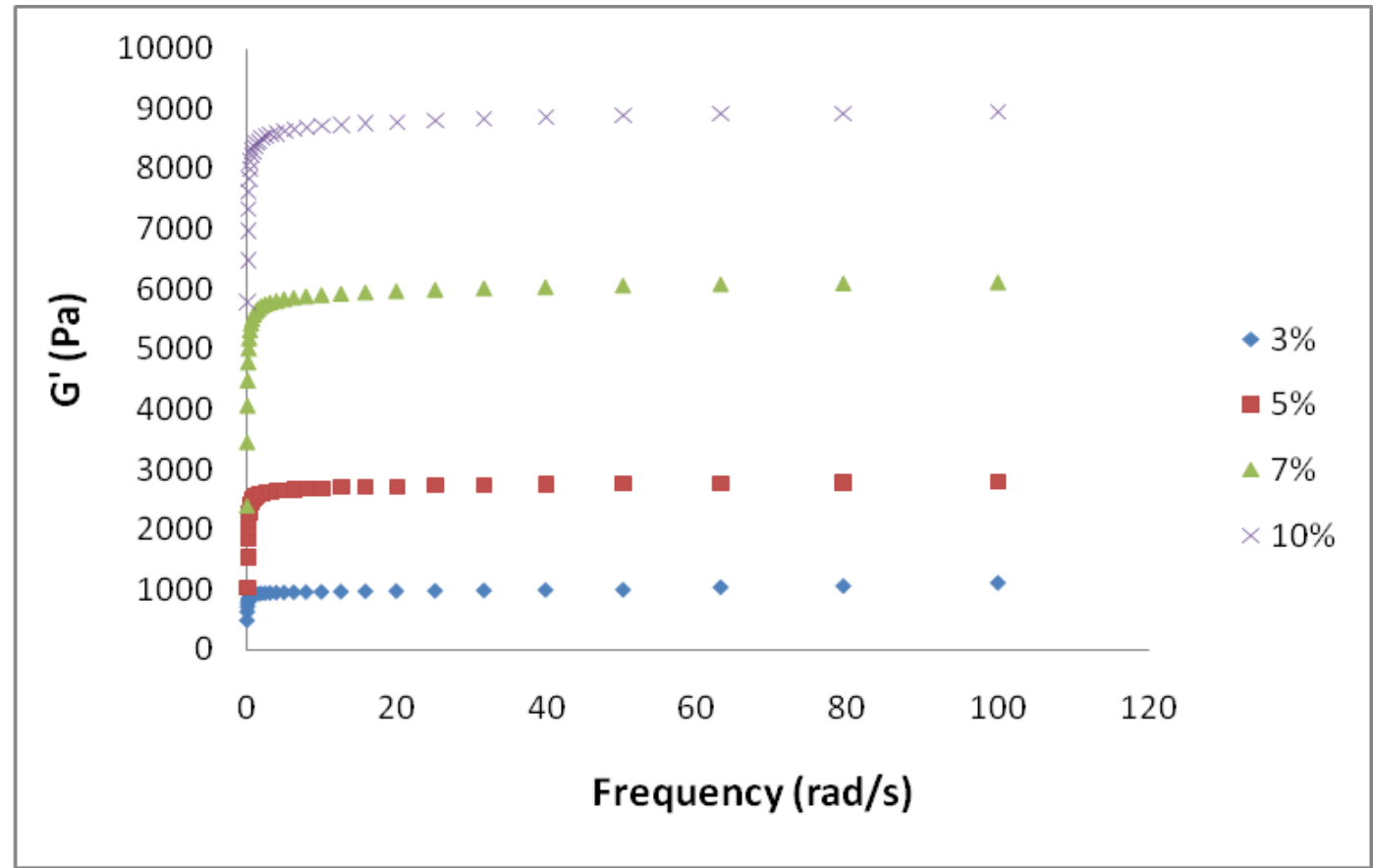

Figure 6

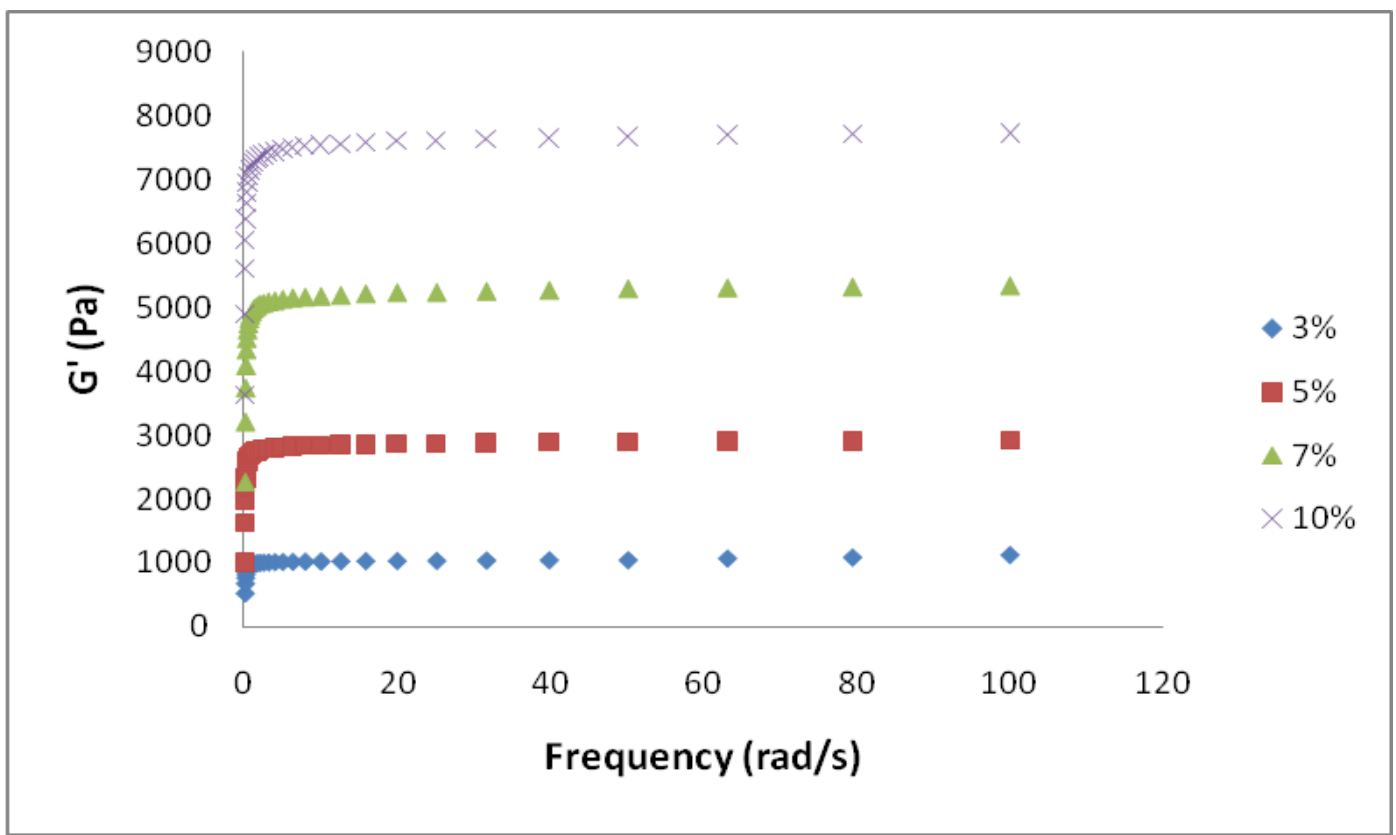


Figure 7

a)

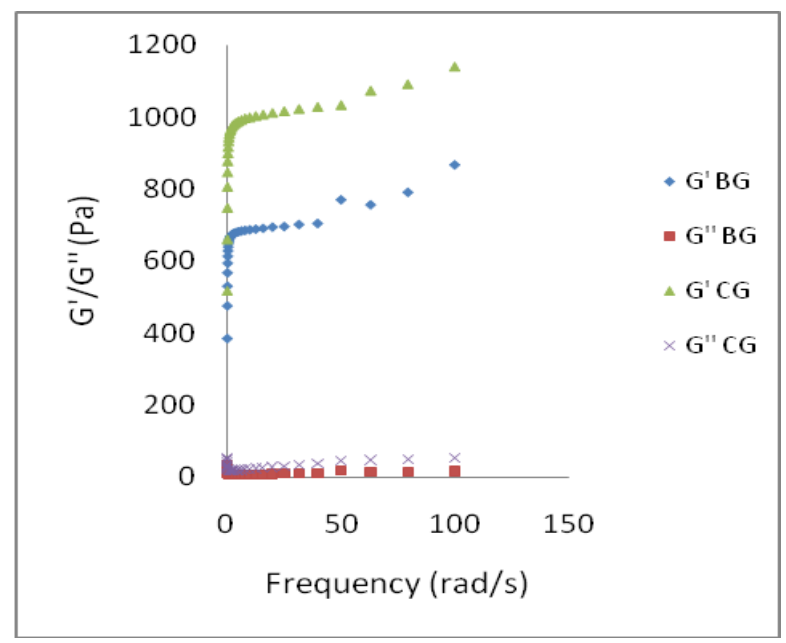

c)

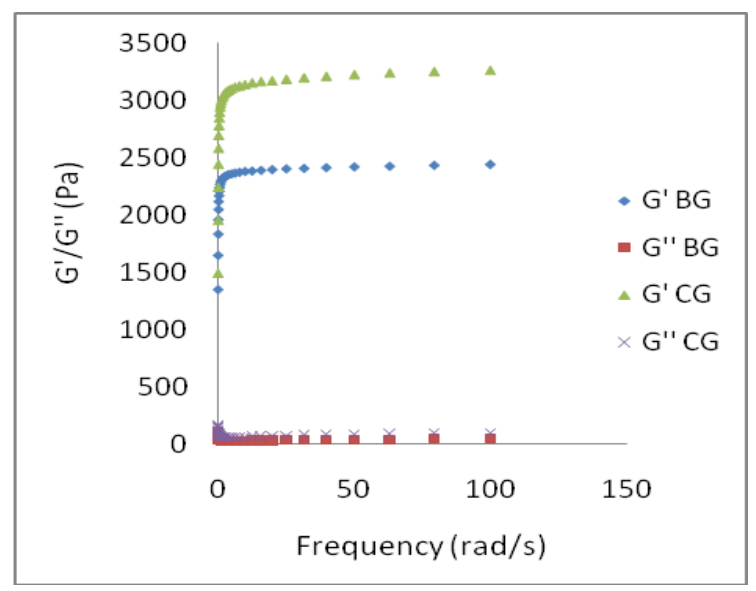

b)

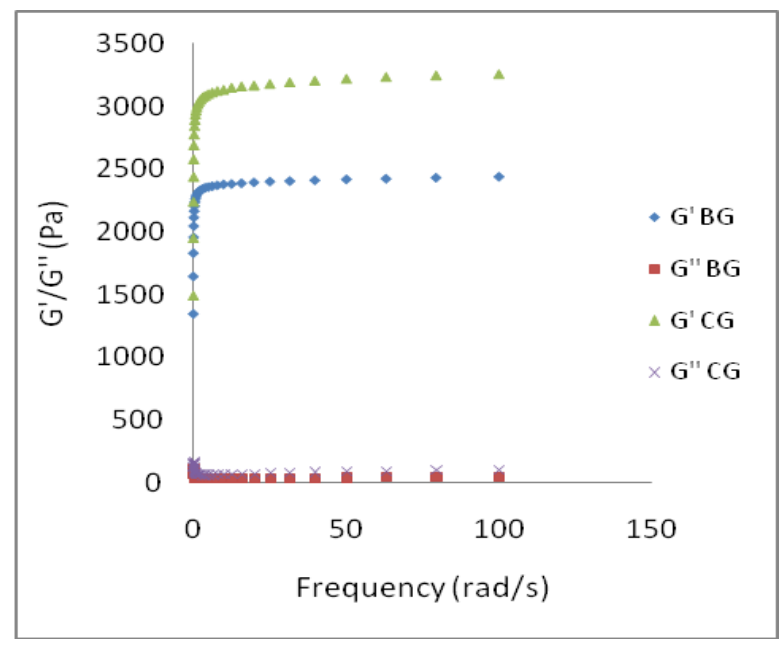

d)

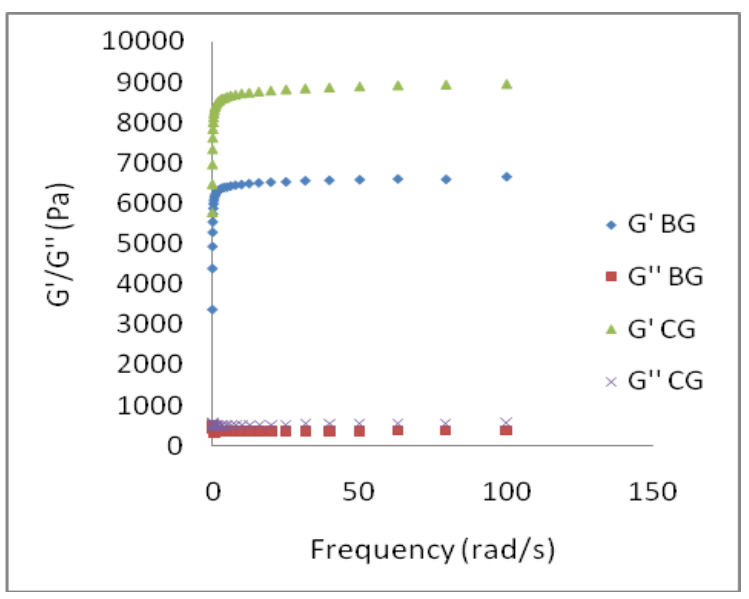


Figure 8

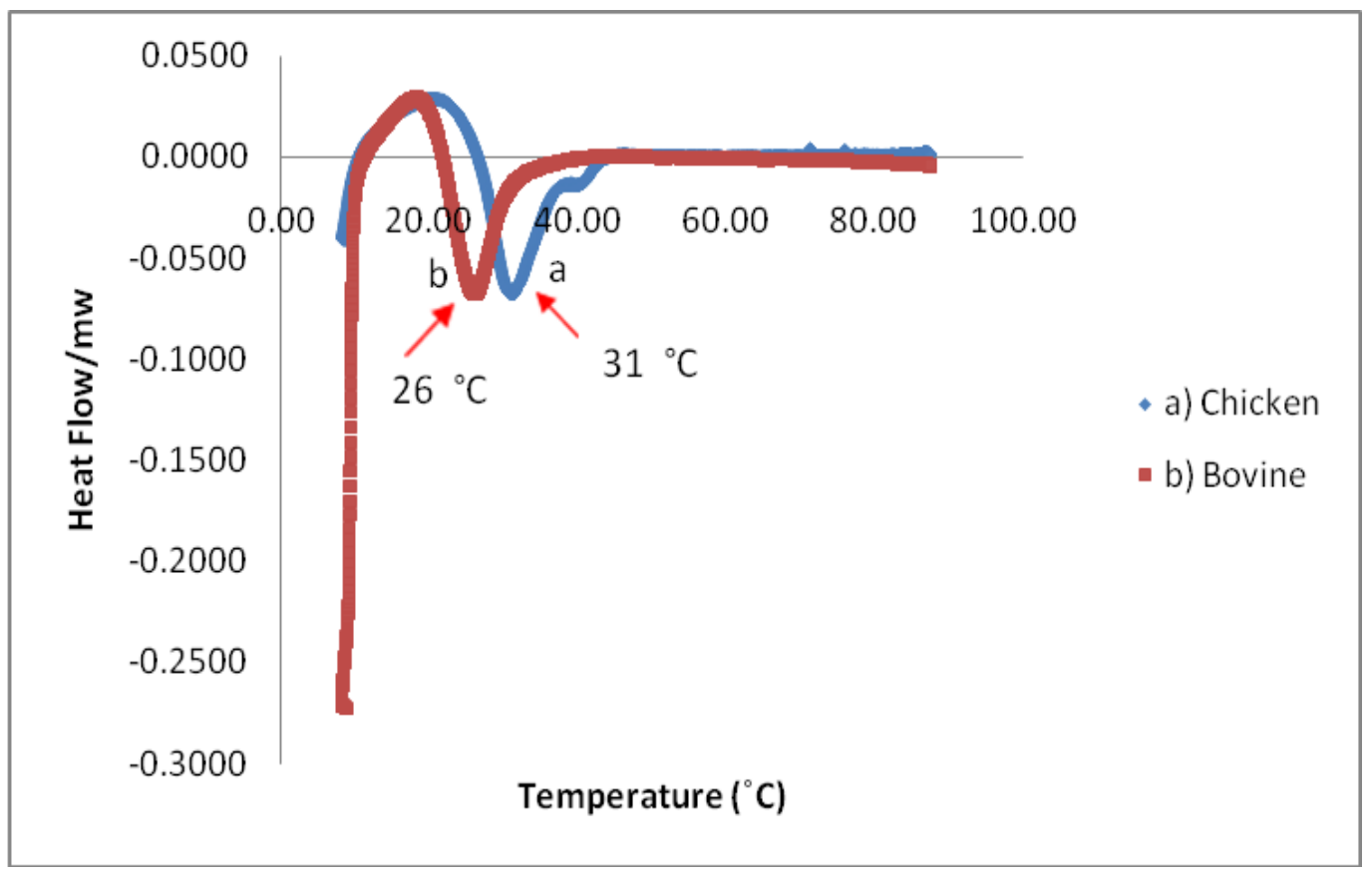

